\title{
Orange juice $v s$ vitamin C: effect on hydrogen peroxide-induced DNA damage in mononuclear blood cells
}

\author{
Serena Guarnieri*, Patrizia Riso and Marisa Porrini \\ Department of Food Science and Microbiology, Division of Human Nutrition, University of Milan, 20133 Milan, Italy \\ (Received 29 June 2006 - Revised 27 October 2006 - Accepted 30 October 2006)
}

\begin{abstract}
The intake of fruits rich in vitamin $\mathrm{C}$ seems to increase the antioxidant defence of the organism. However, it is still not clear whether vitamin $\mathrm{C}$ alone is responsible for this effect. The aim of the present investigation was to study the effect of the intake of a single portion of blood orange juice (BOJ, $300 \mathrm{ml}$, providing $150 \mathrm{mg}$ vitamin C) on mononuclear blood cell (MNBC) DNA damage, compared with a drink supplemented with the same amount of vitamin C (C-drink) or sugars (S-drink). Seven young healthy subjects were randomised in a repeated-measures design in which they received each drink on different occasions, 2 weeks apart. Blood samples were collected at baseline, every hour for $8 \mathrm{~h}$, and at $24 \mathrm{~h}$ after the intake of each drink. Vitamin $\mathrm{C}$ was analysed at each time point by HPLC, whereas $\mathrm{H}_{2} \mathrm{O}_{2}$-induced MNBC DNA damage was evaluated at 0,3 and $24 \mathrm{~h}$ by means of the comet assay. Plasma vitamin $\mathrm{C}$ concentration increased similarly following BOJ or C-drink intake and was not affected by the S-drink. DNA damage significantly decreased $3 \mathrm{~h}$ after BOJ intake (about $18 \% ; P<0.01)$ and remained constant at $24 \mathrm{~h}($ about $16 \% ; P<0.01)$. No effect of the C-drink and S-drink was observed. In conclusion, the intake of a single portion of BOJ provided an early protection of MNBC against oxidative DNA damage; however, the protective effect of BOJ was not explained by vitamin $\mathrm{C}$ alone, thus other phytochemicals could be involved.
\end{abstract}

Orange juice: Vitamin C: DNA damage: Plasma: Mononuclear blood cells

Consumers are generally aware of the health effects of consuming oranges as a rich source of vitamin C. A wide variety of orange derivatives are currently available in several countries as well as on the European market, representing a convenient alternative to the fresh fruit. Among them, freshly squeezed and pasteurised orange juice (containing $100 \%$ orange juice) is the most consumed in Italy (Molfino, 2004). The nutritional profile of this product is similar to that of the fresh fruit (Di Mauro et al. 2001). These products contain high amounts of vitamin $\mathrm{C}$ and lower amounts of other phytochemicals such as carotenoids (namely $\beta$-cryptoxanthin, lutein, zeaxanthin and $\beta$-carotene) and polyphenols (hesperidin, naringenin, cyanidin-3-glucoside, mainly in blood oranges).

The beneficial properties of oranges and their derivatives have been widely investigated. In particular, the inhibition of breast cancer cell proliferation (So et al. 1996), decrease of colon tumorigenesis (Miyagi et al. 2000) and antimutagenic properties (Franke et al. 2006) have been evidenced in cellculture and animal models. Moreover, in vivo studies performed on human subjects support a role for orange juice in the protection against oxidative damage to DNA (Franke et al. 2005; Riso et al. 2005).

Among the compounds present in orange juice, vitamin $\mathrm{C}$ seems to be the most effective antioxidant, as demonstrated by several in vitro studies (Szeto et al. 2002; Proteggente et al. 2002).
Many in vivo studies have investigated the role of vitamin $\mathrm{C}$ in the protection against oxidative-induced DNA damage: single-dose trials showed significant antioxidant protection (Green et al. 1994; Panayiotidis \& Collins, 1997), whereas long-term studies revealed mixed outcomes (Møller \& Loft, 2002; Duarte \& Lunec, 2005).

These discrepancies could be explained by differences in vitamin $\mathrm{C}$ absorption (many factors could be involved; for example, source, amount, characteristics of subjects, etc). In particular, high fluctuations in plasma ascorbic acid may be less beneficial in the protection against DNA damage, as recently reported (Møller et al. 2004).

As regards studies evaluating the effect of orange juice intake on DNA damage, results seem to support a protective effect (Franke et al. 2005, Riso et al. 2005). We recently found an inverse correlation between plasma vitamin $\mathrm{C}$ concentration and $\mathrm{H}_{2} \mathrm{O}_{2}$-induced DNA damage following regular consumption of blood orange juice (BOJ) for $21 \mathrm{~d}$, suggesting a possible protective role for vitamin C (Riso et al. 2005). This increased protection may be due to vitamin $\mathrm{C}$, even if other compounds could be involved.

The aim of the present study was to further extend our understanding of the effect of the intake of one small portion of blood orange juice or vitamin $\mathrm{C}$ dissolved in water on mononuclear blood cell (MNBC) resistance to DNA damage.

\footnotetext{
Abbreviations: BOJ, blood orange juice; C-drink, water with added vitamin C; MNBC, mononuclear blood cell; S-drink, water with added sugars.

* Corresponding author: Dr Serena Guarnieri, fax +39 02503 16071, email serena.guarnieri@unimi.it
} 


\section{Subjects and methods}

\section{Subjects and study design}

Seven healthy, non-smoking female volunteers (age 26.0 (SD 2.1) years, BMI 20.1 (SD 1.4) kg/m²) were enrolled on the basis of a questionnaire concerning their food habits. Vegetarians and anyone taking medication or supplements were excluded from the study.

Subjects were divided into a randomised repeated-measures design in which they had to consume different drinks consisting of BOJ, vitamin $\mathrm{C}$ added to water (C-drink) or sugars added to water (S-drink). Single portions $(300 \mathrm{ml})$ of the drinks under study were supplied in the morning to fasting volunteers on three different occasions, 2 weeks apart.

Finger-prick blood samples were drawn from fasting volunteers into heparinised microtubes. After the intake of each drink, blood samples were collected every hour for $8 \mathrm{~h}$ and at $24 \mathrm{~h}$. Vitamin $\mathrm{C}$ was analysed in every sample taken, while $\mathrm{H}_{2} \mathrm{O}_{2}$-induced MNBC DNA damage was determined at $0 \mathrm{~h}, 3 \mathrm{~h}$ (peak of vitamin $\mathrm{C}$ in plasma) and $24 \mathrm{~h}$. A standardised meal consisting of antioxidant-controlled foods (bread with ham, cheese, milk ice-cream and decaffeinated coffee with sugar) was provided $4 \mathrm{~h}$ after the intake of the drink.

The present study was approved by the local ethics committee. All subjects gave their written informed consent before participation.

\section{Characteristics and analysis of the drinks}

The commercial BOJ used (freshly squeezed and pasteurised, containing $100 \%$ orange juice; Fattoria Scaldasole, Italy) is produced by squeezing, immediate freezing and light pasteurising before aseptic packaging and storage at $4^{\circ} \mathrm{C}$. A $100 \mathrm{ml}$ portion of juice contained $50.5 \pm 0.3 \mathrm{mg}$ vitamin $\mathrm{C}, 68.6$ (SD 1.9) mg hesperidin, 8.2 (SD 0.6) mg narirutin (C Gardana, S Guarnieri, P Riso, P Simonetti, M Porrini, unpublished results) and 12.7 (SD 0.2) $\mathrm{g}$ sugars (fructose, glucose and sucrose in the ratio $1: 1: 2$ ).

Vitamin C was determined by HPLC: the chromatographic system consisted of a model 510 system pump (Waters Corp., Milford, MA, USA), a $5 \mu \mathrm{m}$ Atlantis $\mathrm{C}_{18}$ column $(250 \times 4.6 \mathrm{~mm}$ internal diameter; Waters, Dublin, Republic of Ireland) and detection was achieved at $245 \mathrm{~nm}$ (UV-Vis detector Varian 9050; Varian Inc., Palo Alto, CA, USA). Samples were eluted $(1.4 \mathrm{ml} / \mathrm{min})$ with a mobile phase of $0.1 \%$ formic acid. The sample injection volume was $50 \mu 1$. Chromatographic data were acquired by a Millennium $4 \cdot 0$ Workstation (Waters Corp). Vitamin C standards (Sigma Chemicals, St Louis, MO, USA) were prepared in $10 \%$ metaphosphoric acid buffer in the range of $5-20 \mu \mathrm{g} / \mathrm{ml}$.

Flavanone concentrations in BOJ were determined by LCMS/MS by means of a chromatographic system consisting of an Alliance model 2695 equipped with a model 2996 (Waters Corp) photodiode array detector and a Quattro Micro triple quadrupole mass spectrometer (Micromass, Beverly, MA, USA).

Carbohydrate concentrations were determined by LC-MS. The HPLC system was an Alliance (Waters) coupled to a Quattro Micro triple quadrupole mass spectrometer (Micromass) equipped with an atmospheric pressure chemical ionisation source operating in negative mode.
Vitamin C powder was supplied by Phoenix Srl (Peschiera Borromeo, Italy). Its purity was checked by HPLC (about $99 \%$ ) and used to calculate the amount of powder to add to water in order to have a drink with the same amount of vita$\min \mathrm{C}$ as in the juice (the $\mathrm{C}$-drink). The final vitamin $\mathrm{C}$ concentration in the solution was also measured. The C-drink was prepared just after the volunteers arrived at the laboratory. It was immediately covered and served.

Both the amount of BOJ and C-drink supplied to volunteers $(300 \mathrm{ml})$ provided $150 \mathrm{mg}$ vitamin $\mathrm{C}$; BOJ and the S-drink provided $38 \mathrm{~g}$ sugars.

\section{Determination of vitamin $C$ in plasma}

The extraction was performed in duplicate on $100 \mu$ l plasma (fresh sample) to which $100 \mu 110 \%$ metaphosphoric acid solution was added. After vortexing and centrifuging for $1 \mathrm{~min}$, $100 \mu \mathrm{l}$ of the supernatant fraction were immediately injected for HPLC analysis (conditions have been previously described). Vitamin C standards were prepared daily for plasma analysis.

\section{Evaluation of mononuclear blood cell DNA resistance to oxidative damage}

In order to verify the hypothesis that a transient increase in plasma antioxidant compounds following the test drinks might improve cell protection, we evaluated cell ability to counteract an exogenous oxidative insult able to cause consistent DNA damage, as already applied in previous studies (Riso et al. 2004; Porrini et al. 2005).

The resistance of MNBC DNA against oxidative stress (strand breaks after treatment with $\mathrm{H}_{2} \mathrm{O}_{2}(500 \mu \mathrm{mol} / \mathrm{l})$ for $5 \mathrm{~min}$ ) was evaluated by means of the Comet assay as previously reported in detail (Riso et al. 1999). One hundred cells for each slide were electronically captured $(400 \times$ magnification) using an epifluorescence microscope (BX 60 OLYMPUS) equipped with an excitation filter BP520-550, dichroic beam-splitter DM565 and BA580-IF barrier filter (OLYMPUS, Olympus Italia S.R.L., Milan, Italy). The light source was a $100 \mathrm{~W} \mathrm{Hg}$ lamp (Olympus Italia S.R.L.). The microscope was attached to a high-sensitivity charged coupled device (CCD) video camera and to a computer provided with an image analysis system (Comet Program exploited on Image Pro-Plus; Immagini e Computer, Bareggio, Milan, Italy) and set to calculate the levels of strand breaks, as percentage DNA in tail.

For each subject, the average percentage DNA in tail of control cells (cells that were not treated with $\mathrm{H}_{2} \mathrm{O}_{2}$ ) was subtracted from the average percentage DNA in tail of treated cells.

\section{Statistical analysis}

Statistical analysis was performed with STATISTICA software (Statsoft Inc., Tulsa, OK, USA). A two-way ANOVA for repeated measures design was employed to compare plasma vitamin $\mathrm{C}$ concentration after BOJ, C-drink or S-drink intake and to evaluate the effect of each drink on DNA damage registered at 3 and $24 \mathrm{~h}$. Differences between means were determined by Tukey's test $(\alpha=0 \cdot 05)$. 


\section{Results}

\section{Plasma vitamin $C$ concentrations}

Plasma vitamin $\mathrm{C}$ concentrations measured from baseline to $24 \mathrm{~h}$ after the consumption of each drink are represented in Table 1. Vitamin C concentrations at baseline were not significantly different in the three treatments. They increased significantly $1 \mathrm{~h}$ after both BOJ and C-drink consumption $(P<0 \cdot 001)$ and reached a peak at $2-3 \mathrm{~h}$ (average increase of $26.5 \mu \mathrm{mol} / \mathrm{l}$ for BOJ and $33.3 \mu \mathrm{mol} / \mathrm{l}$ for the C-drink, corresponding to 34 and $45 \%$ respectively). The increases in vitamin $\mathrm{C}$ concentration registered at 2 and $3 \mathrm{~h}$ were not significantly different after the two drinks containing vitamin $\mathrm{C}$. Then, the vitamin concentration significantly decreased after $4 \mathrm{~h}$ (BOJ; $P<0.05)$ and $6 \mathrm{~h}$ (C-drink; $P<0.005)$. On the whole, ANOVA did not show any significant difference between plasma vitamin $\mathrm{C}$ responses following $\mathrm{BOJ}$ or C-drink consumption. In addition, area under the curve was used to evaluate the response rate of plasma ascorbic acid after BOJ or C-drink intake for each subject. No significant difference was registered between mean values (724 (SD 121) $\mu \mathrm{mol} /$ $1 \times \mathrm{h}$ for BOJ and $772(\mathrm{SD} \mathrm{102)} \mu \mathrm{mol} / \mathrm{l} \times \mathrm{h}$ for the $\mathrm{C}$-drink).

At $24 \mathrm{~h}$ vitamin $\mathrm{C}$ was comparable and not different from the baseline values in each trial. Similar trends were observed in a previous study carried out in our laboratory (amount of vitamin $\mathrm{C}$ administered was $564 \mathrm{mg}$ ).

$\mathrm{S}$-drink intake did not affect plasma vitamin $\mathrm{C}$ concentration.

\section{Mononuclear blood cell DNA resistance to oxidative damage}

Table 2 outlines the results of DNA strand breaks registered at each time point $(0,3$ and $24 \mathrm{~h})$ within each treatment (BOJ, C-drink and S-drink). Values refer to untreated cells (controls), $\mathrm{H}_{2} \mathrm{O}_{2}$-treated cells and subtracted values (treated minus untreated cells).

Strand breaks in controls before each treatment were not significantly different and were comparable after drink intake.

Two-way ANOVA performed on subtracted values showed a significant effect of the interaction between treatment (BOJ,

Table 1. Plasma vitamin $\mathrm{C}$ concentration from baseline to $24 \mathrm{~h}$ after the intake of blood orange juice (BOJ), vitamin $\mathrm{C}$ dissolved in water (C-drink) and sugars in water (S-drink)

\begin{tabular}{|c|c|c|c|c|c|c|}
\hline \multirow[b]{3}{*}{ Time (h) } & \multicolumn{6}{|c|}{ Plasma vitamin $C(\mu \mathrm{mol} / \mathrm{l})$} \\
\hline & \multicolumn{2}{|c|}{ BOJ } & \multicolumn{2}{|c|}{ C-drink } & \multicolumn{2}{|c|}{ S-drink } \\
\hline & Mean & SD & Mean & SD & Mean & SD \\
\hline 0 & $76 \cdot 9^{\mathrm{a}}$ & $22 \cdot 1$ & $73 \cdot 4^{\mathrm{a}}$ & $13 \cdot 0$ & $73 \cdot 3^{\mathrm{a}}$ & $14 \cdot 0$ \\
\hline 1 & $98 \cdot 3^{\mathrm{c}}$ & $27 \cdot 0$ & $98 \cdot 5^{b, c, d}$ & $12 \cdot 1$ & $72 \cdot 3^{\mathrm{a}}$ & $14 \cdot 6$ \\
\hline 2 & $103 \cdot 4^{\mathrm{b}, \mathrm{c}}$ & $23 \cdot 2$ & $106 \cdot 7^{c}$ & $16 \cdot 3$ & $75 \cdot 1^{a}$ & $17 \cdot 7$ \\
\hline 3 & $99 \cdot 2^{\mathrm{c}}$ & $18 \cdot 9$ & $103 \cdot 3^{c}$ & $19 \cdot 8$ & $74.7^{\mathrm{a}}$ & $16 \cdot 6$ \\
\hline 4 & $88 \cdot 0^{b, d}$ & $13 \cdot 0$ & $99 \cdot 7^{\mathrm{c}, \mathrm{d}}$ & $18 \cdot 1$ & $73.9^{\mathrm{a}}$ & $15 \cdot 6$ \\
\hline 5 & $87 \cdot 3^{\mathrm{b}, \mathrm{d}}$ & $13 \cdot 6$ & $98 \cdot 0^{c, d}$ & $16 \cdot 3$ & $72 \cdot 6^{\mathrm{a}}$ & $14 \cdot 8$ \\
\hline 6 & $86 \cdot 7^{\mathrm{a}, \mathrm{b}, \mathrm{d}}$ & $13 \cdot 6$ & $94 \cdot 2^{c, d}$ & 13.8 & $74.4^{\mathrm{a}}$ & $15 \cdot 3$ \\
\hline 7 & $82 \cdot 6^{\mathrm{a}, \mathrm{d}}$ & 14.5 & $91 \cdot 2^{b, d}$ & 9.9 & $76 \cdot 4^{\mathrm{a}}$ & $16 \cdot 8$ \\
\hline 8 & $80 \cdot 9^{\mathrm{a}, \mathrm{d}}$ & 13.5 & $86 \cdot 5^{\mathrm{a}, \mathrm{d}}$ & $10 \cdot 5$ & $71 \cdot 0^{\mathrm{a}}$ & $16 \cdot 8$ \\
\hline 24 & $73 \cdot 1^{a}$ & $17 \cdot 3$ & $76 \cdot 1^{\mathrm{a}}$ & $13 \cdot 1$ & $65 \cdot 5^{\mathrm{a}}$ & $13 \cdot 2$ \\
\hline
\end{tabular}

Table 2. Strand breaks in mononuclear blood cells, evaluated by the comet assay, at baseline, and at 3 and $24 \mathrm{~h}$ after the intake of blood orange juice (BOJ), vitamin $\mathrm{C}$ dissolved in water (C-drink) and sugars in water (S-drink)*

(Mean values and standard deviations)

\begin{tabular}{|c|c|c|c|c|c|c|}
\hline \multirow[b]{3}{*}{ Time (h) } & \multicolumn{6}{|c|}{ DNA damage (\% DNA in tail) } \\
\hline & \multicolumn{2}{|c|}{ BOJ } & \multicolumn{2}{|c|}{ C-drink } & \multicolumn{2}{|c|}{ S-drink } \\
\hline & Mean & SD & Mean & SD & Mean & SD \\
\hline \multicolumn{7}{|c|}{ Untreated cells (controls) } \\
\hline 0 & $2 \cdot 4$ & $1 \cdot 3$ & $2 \cdot 3$ & 0.7 & 3.0 & 0.4 \\
\hline 3 & $2 \cdot 5$ & 1.4 & 1.8 & 0.7 & $3 \cdot 0$ & 0.4 \\
\hline 24 & $2 \cdot 8$ & 0.7 & $2 \cdot 3$ & 0.5 & $3 \cdot 1$ & 0.4 \\
\hline \multicolumn{7}{|c|}{$\mathrm{H}_{2} \mathrm{O}_{2}$-treated cells } \\
\hline 0 & $65 \cdot 3^{\mathrm{a}}$ & $6 \cdot 3$ & $57 \cdot 9^{\mathrm{a}}$ & 12.5 & $60 \cdot 0^{\mathrm{a}}$ & 6.4 \\
\hline 3 & $54 \cdot 4^{\mathrm{b}}$ & $10 \cdot 4$ & $61.9^{\mathrm{a}}$ & $13 \cdot 2$ & $57 \cdot 3^{\mathrm{a}}$ & 5 \\
\hline 24 & $54 \cdot 7^{\mathrm{b}}$ & 14.4 & $59 \cdot 0^{\mathrm{a}}$ & 14.6 & $61 \cdot 2^{\mathrm{a}}$ & 5.5 \\
\hline \multicolumn{7}{|c|}{ Subtracted values (treated minus untreated cells) } \\
\hline 0 & $62 \cdot 9^{\mathrm{a}}$ & $6 \cdot 3$ & $55 \cdot 6^{\mathrm{a}}$ & $12 \cdot 8$ & $56 \cdot 9^{\mathrm{a}}$ & $6 \cdot 3$ \\
\hline 3 & $51 \cdot 9^{b}$ & $9 \cdot 9$ & $59 \cdot 4^{a}$ & $13 \cdot 2$ & $54 \cdot 3^{\mathrm{a}}$ & $6 \cdot 0$ \\
\hline 24 & $52 \cdot 0^{b}$ & 14.5 & $56 \cdot 7^{\mathrm{a}}$ & $15 \cdot 0$ & $58 \cdot 1^{\mathrm{a}}$ & 5.5 \\
\hline
\end{tabular}

a,b Mean values within a column with unlike superscript letters were significantly different $(P<0.05)$

* Oxidative treatment was performed by means of $\mathrm{H}_{2} \mathrm{O}_{2}(500 \mu \mathrm{mol} / \mathrm{l})$ for $5 \mathrm{~min}$. Average values of untreated cells (controls), $\mathrm{H}_{2} \mathrm{O}_{2}$-treated cells and subtracted values (treated minus untreated cells) are outlined.

C-drink or S-drink) and time $(0,3$ and $24 \mathrm{~h})(P<0 \cdot 005)$. A significant increase in resistance to DNA damage was registered $3 \mathrm{~h}$ after BOJ intake (about $18 \% ; P<0.01$ ). This trend was found in all the subjects and the protection observed remained nearly constant at $24 \mathrm{~h}$ (with a decrease of about $16 \%$; $P<0.01)$. In contrast, $\mathrm{C}$-drink or $\mathrm{S}$-drink consumption did not affect DNA damage.

ANOVA was also performed on single-strand breaks after $\mathrm{H}_{2} \mathrm{O}_{2}$ treatment (without subtracting controls), confirming the results previously reported.

\section{Correlations}

Baseline vitamin $\mathrm{C}$ concentrations were not correlated to the maximum increase registered for each subject, suggesting that plasma vitamin $\mathrm{C}$ increases were independent from baseline values. Also the reduction of $\mathrm{H}_{2} \mathrm{O}_{2}$-induced DNA damage (at $3 \mathrm{~h}$ ) was independent of initial levels of oxidative-induced DNA damage.

Moreover, despite an inverse correlation observed between plasma vitamin $\mathrm{C}$ and DNA damage $3 \mathrm{~h}$ after orange juice intake, it was not confirmed at $24 \mathrm{~h}$.

\section{Discussion}

The results of the present study provide further evidence that whole foods can increase cell resistance to oxidative stress better than single compounds, and that BOJ is a source of bioavailable vitamin $\mathrm{C}$.

In fact, we have shown a decrease in $\mathrm{H}_{2} \mathrm{O}_{2}$-induced oxidative DNA damage in MNBC $3 \mathrm{~h}$ after the consumption of a moderate amount of BOJ and this effect was maintained until $24 \mathrm{~h}$. The protection observed at $3 \mathrm{~h}$ corresponded to an increase in plasma vitamin $\mathrm{C}$ concentration, but at $24 \mathrm{~h}$ vitamin $\mathrm{C}$ returned to its baseline value, suggesting that different 
compounds were also involved. This observation is supported by the fact that the same amount of vitamin $\mathrm{C}$, provided as a supplement, did not affect cell DNA damage, despite the similar increase in plasma vitamin $\mathrm{C}$.

Other authors have reported positive effects of single doses of vitamin $\mathrm{C}$ on DNA damage in healthy volunteers, with the highest DNA protection within $4 \mathrm{~h}$ after ingestion. However, the amount of vitamin $\mathrm{C}$ used in these studies was higher than in the present study: $35 \mathrm{mg}$ (Green et al. 1994) and $1 \mathrm{~g}$ (Panayiotidis \& Collins, 1997). Moreover, the intervention with vitamin $\mathrm{C}$ for weeks or months provided conflicting results regarding the modulation of DNA damage in human subjects, as recently reviewed by Møller \& Loft (2002). In agreement with these authors, we think that, beyond metabolic and genetic individual differences, one possible explanation for the discrepancies among different studies could be related to the initial plasma vitamin $\mathrm{C}$ levels in different groups of volunteers.

In fact, it has been suggested that subjects with basal levels higher than $60 \mu \mathrm{mol} / 1$ could not benefit from vitamin $\mathrm{C}$ supplementation (Prieme et al. 1997; Porkkala-Sarataho et al. 2000). In contrast, vitamin $C$ supplementation seems to be effective in patients with conditions associated with oxidative stress and low plasma vitamin C levels (Duarte \& Lunec, 2005). In the present study, we used healthy non-smoker subjects with high baseline levels of plasma vitamin C (average of about $77 \mu \mathrm{mol} / \mathrm{l}$ ), and this could explain the lack of effect observed when one single dose of supplement was provided. Another possible explanation could be related to the intracellular vitamin $\mathrm{C}$ saturation that has been reported to occur before plasma saturation (Duarte \& Lunec, 2005). To clarify this fact, it might have been useful to determine vitamin $\mathrm{C}$ concentration in MNBC.

Besides the previous observations, the interesting finding coming from the present study is that our healthy subjects benefited from the consumption of a small single portion of BOJ. In fact, despite the small number of subjects enrolled, all of them showed an increase in resistance to DNA damage.

This suggests that several compounds (for example, cyanidin-3-glucoside, flavanones, carotenoids, etc) other than vitamin C are bioavailable from BOJ (Riso et al. 2005; Franke et al. 2006) and could be involved in the protective effect observed. These compounds could act in synergy or sequentially, depending on their absorption. This could help in explaining the correlation between DNA damage and vitamin $\mathrm{C}$ concentration $3 \mathrm{~h}$ after BOJ intake but the lack of correlation at $24 \mathrm{~h}$.

We also evaluated whether sugars present in the juice could affect DNA damage; some authors found that fructose could be responsible or take part in the antioxidant effect of some fruit, causing an increase in plasma urate (Lotito \& Frei, 2004). The present study does not support a role for fructose, glucose and sucrose on cell antioxidant protection, at least against DNA damage.

The present results are in agreement with those previously reported by Collins et al. (2001) who found a reduction of single strand breaks at $3 \mathrm{~h}$, which persisted after 8 and $24 \mathrm{~h}$ from the intake of a single portion of kiwi-fruit juice (providing about $415 \mathrm{mg}$ vitamin $\mathrm{C}$ ). In addition to this, the authors, by using an in vitro test, showed that an extract of kiwi fruit was more effective than a solution of vitamin $C$ (with the same concentration), in protecting DNA from oxidative damage.

In conclusion, we reported, in a small number of subjects, that the protective effect of the intake of a small portion of BOJ is not accounted for by vitamin $\mathrm{C}$ alone as no effect of the vitamin supplementation was observed. In addition, the maintenance of DNA protection for $24 \mathrm{~h}$ observed after BOJ intake supports the importance of the regular consumption of fruit and vegetables, rich in protective compounds, in order to limit cell susceptibility to oxidative damage.

\section{Acknowledgements}

We gratefully acknowledge Phoenix Srl (Peschiera Borromeo, Milan, Italy) for supplying the vitamin $\mathrm{C}$ supplement and $\mathrm{Dr}$ Claudio Gardana for the HPLC analysis of sugars and flavanones.

\section{References}

Collins BH, Horská A, Hotten PM, Riddoch C \& Collins AR (2001) Kiwifruit protects against oxidative DNA damage in human cells and in vitro. Nutr Cancer 39, 148-153.

Di Mauro A, Maccarone E \& Marchese D (2001) Problemi e prospettive della produzione di succo di arance pigmentate (Problems and perspectives in the production of pigmented orange juice). Frutticoltura 2, 23-27.

Duarte TL \& Lunec J (2005) Review: When is an antioxidant not an antioxidant? A review of novel actions and reactions of vitamin C. Free Rad Res 39, 671-686.

Franke AA, Cooney RV, Henning M \& Custer LJ (2005) Bioavailability and antioxidant effects of orange juice in humans. J Agric Food Chem 53, 5170-5178.

Franke SI, Prá D, Giulian R, Dias JF, Yoneama ML, da Silva J, Erdtmann B \& Henriques JA (2006) Influence of orange juice in the levels and in the genotoxicity of iron and copper. Food Chem Toxicol 44, 425-435.

Green MHL, Lowe JE, Waugh APW, Alridge KE, Cole J \& Arlett CF (1994) Effect of diet and vitamin C on DNA strand breakage in freshly-isolated human white blood cells. Mutat Res 316, 91-102.

Lotito SB \& Frei B (2004) The increase in human plasma antioxidant capacity after apple consumption is due to the metabolic effect of fructose on urate, not apple-derived antioxidant flavonoids. Free Rad Biol Med 37, 251-258.

Miyagi Y, Om AS, Chee KM \& Bennink MR (2000) Inhibition of azomethane-induced colon cancer by orange juice. Nutr Cancer 36, 224-229.

Molfino M (2004) Incrementi a due cifre per i succhi di frutta. Meglio se dal gusto classico (Two-figure increases for fruit juices. Better if the classic taste). La Rivista di Frutticoltura e Ortofloricoltura 10, $68-70$.

Møller P \& Loft S (2002) Oxidative DNA damage in human white blood cells in dietary antioxidant intervention studies. Am J Clin Nutr 76, 303-310.

Møller P, Viscovich M, Lykkesfeldt J, Loft S, Jensen A \& Poulsen HE (2004) Vitamin C supplementation decreases oxidative DNA damage in mononuclear blood cells of smokers. Eur J Nutr 43, 267-274.

Panayiotidis Y \& Collins AR (1997) Ex vivo assessment of lymphocyte antioxidant status using the comet assay. Free Rad Res 27, 533-537.

Porkkala-Sarataho E, Salonen JT, Nyyssönen K, Kaikkonen J, Salonen R, Ristonmaa U, Diczfalusy U, Brigelius-Flohe R, Loft S \& Poulsen HE (2000) Long-term effects of vitamin E, vitamin C, 
and combined supplementation on urinary 7-hydro-8-oxo-2'-deoxyguanosine, serum cholesterol oxidation and oxidation resistance of lipids in nondepleted men. Arterioscler Thromb Vasc Biol 20, 2087-2093.

Porrini M, Riso P, Brusamolino A, Berti C, Guarnieri S \& Visioli F (2005) Daily intake of a formulated tomato drink affects carotenoid plasma and lymphocyte concentrations and improves cellular antioxidant protection. Br J Nutr 93, 93-99.

Prieme H, Loft S, Nyyssönen K, Salonen JT \& Poulsen HE (1997) No effect of supplementation with vitamin E, ascorbic acid or coenzyme Q10 on oxidative DNA damage estimated by 8-oxo7,8-dihydro-2'-deoxyguanosine excretion in smokers. Am J Clin Nutr 65, 503-507.

Proteggente AR, Pannala AS, Paganga G, Buren LV, Wagner E, Wiseman S, Van De Pui F, Dacombe C \& Rice-Evans CA (2002) The antioxidant activity of regularly consumed fruit and vegetables reflects their phenolic and vitamin $\mathrm{C}$ composition. Free Rad Res 36, 217-233.
Riso P, Pinder A, Santangelo A \& Porrini M (1999) Does tomato consumption effectively increase the resistance of lymphocyte DNA to oxidative damage?. Am J Clin Nutr 69, 712-718.

Riso P, Visioli F, Erba D, Testolin G \& Porrini M (2004) Lycopene and vitamin $\mathrm{C}$ concentrations increase in plasma and lymphocytes after tomato intake. Effects on cellular antioxidant protection. Eur J Clin Nutr 58, 1350-1358.

Riso P, Visioli F, Gardana C, Grande S, Brusamolino A, Galvano F \& Porrini M (2005) Effects of blood orange juice intake on antioxidant bioavailability and on different markers related to oxidative stress. J Agric Food Chem 53, 941-947.

So FV, Guthrie N, Chambers AF, Moussa M \& Carroll KK (1996) Inhibition of human breast cancer cell proliferation and delay of mammary tumorigenesis by flavonoids and citrus juices. Nutr Cancer 26, 167-181.

Szeto YT, Tomlinson B \& Benzie IFF (2002) Total antioxidant and ascorbic acid content of fresh fruits and vegetables: implications for dietary planning and food preservation. Br J Nutr 87, 55-59. 